\title{
Respon Morfologi dan Fisiologi Genotipe Terung (Solanum melongena L.) terhadap Cekaman Salinitas
}

\author{
Morphological and Physiological Responses of Eggplant (Solanum melongena L.) \\ Genotypes to Salinity Stress
}

\author{
Sobir $^{1 *}$, Miftahudin ${ }^{2}$ dan Susan Helmi ${ }^{3}$
}

Diterima 16 Agustus 2017/Disetujui 07 Februari 2018

\begin{abstract}
Cultivation of eggplant (Solanum melongena L.) needs fertile soils to optimize the yield, however since the fertile land become limited, cultivation of eggplant needs to utilize sub optimal lands such as salin soils. The objective of the research was to analyze morphological and physiological responses of six eggplant genotypes (collection of the Center for Tropical Horticulture Studies), to determine the tolerance of genotypes to salinity stress to be used as tolerant parents in eggplant breeding program. The research was a factorial experiment. It was designed as randomized block design with two factors, which were genotype factor (6 genotypes) and salinity factor (0, 2-4, 5-7, 8$10 \mathrm{mS} \mathrm{cm} \mathrm{cm}^{-1}$ ) with 5 replications. The research was conducted in greenhouse using pot. The morphological evaluation included shoot length, number of leaves, fruit weight, number of branches, shoot biomass, root biomass, and the physiological characters included photosynthesis rate, transpiration rate, stomatal conductance, $\mathrm{CO}_{2}$ intercelluler, leaf relative water contents, and proline accumulation. The results showed that salinity stress decreased all morphological as well as physiological characters in all genotypes, except for proline accumulation that showed increase as the salinity increase. Based on the stress susceptivility index (SSI), there was no eggplant genotypes classified as tolerant to salinity. However, there were two eggplant genotypes, i.e., number 061 and 072, classified as moderat genotypes to salinity stress.
\end{abstract}

Keywords: proline, sensitive, stress susceptibility index, tolerant

ABSTRAK

Budidaya terung (Solanum melongena L.) membutuhkan tanah yang subur untuk mengoptimalkan hasil panen, namun karena lahan subur menjadi terbatas, maka dalam budidaya terung memerlukan pemanfaatan lahan suboptimal seperti tanah yang bersifat salin. Tujuan penelitian ini ialah untuk menganalisis respon morfologi dan fisiologi enam genotipe terung, yang merupakan terung hasil koleksi Pusat Kajian Hortikultura Tropika, untuk menentukan toleransi genotipe terhadap cekaman salinitas yang akan digunakan sebagai tetua toleran pada program pemuliaan tanaman terung. Penelitian ini merupakan percobaan faktorial yang dirancang menggunakan rancangan acak kelompok yang terdiri dari dua faktor yaitu faktor genotipe dengan 6 genotipe dan faktor perlakuan salinitas $(\mathrm{NaCl})$ yang terdiri atas 4 taraf yaitu $0-1,2-4,5-7,8-10 \mathrm{mS} \mathrm{cm}{ }^{-1}$ ) dan diulang sebanyak 5 kali. Penelitian dilakukan di rumah kaca sebagai percobaan pot. Karakter morfologi yang diamati adalah tinggi tanaman, jumlah daun, bobot buah, jumlah cabang, bobot basah tajuk, bobot basah akar, sedangkan karakter fisiologis adalah laju fotosintesis, laju transpirasi, konduktansi stomata, $\mathrm{CO}_{2}$ interselular, kandungan air relatif daun, dan akumulasi prolin. Hasil penelitian menunjukkan bahwa cekaman salinitas menurunkan semua karakter morfologi dan fisiologis pada semua genotipe, kecuali akumulasi prolin yang menunjukkan peningkatan seiring meningkatnya cekaman salinitas. Berdasarkan indeks kepekaan cekaman (SSI), tidak ada genotipe terung yang tergolong toleran terhadap salinitas. Namun, ada dua genotipe terung, yaitu: 061 dan 072, tergolong genotipe moderat terhadap cekaman salinitas.

Kata kunci: indeks kepekaan cekaman, proline, sensitif, toleran

${ }^{1}$ Departemen Agronomi dan Hortikultura, Fakultas Pertanian, Institut Pertanian Bogor

Jl. Meranti, Kampus IPB Darmaga, Bogor 16680

${ }^{2}$ Departemen Biologi, Fakultas Matematika dan Ilmu Pengetahuan Alam, Institut Pertanian Bogor

J1. Meranti, Kampus IPB Darmaga. Bogor 16680.

${ }^{3}$ Mahasiswa Program Studi Biologi Tumbuhan, Sekolah Pascasarjana, Institut Pertanian Bogor

Email: rsobir@yahoo.com (*Penulis korespondensi) 


\section{PENDAHULUAN}

Terung (Solanum melongena L.) merupakan salah satu tanaman sayuran asli daerah tropik yang cukup terkenal di Indonesia dan mudah ditemukan di pasar tradisional dengan harga relatif murah (Sinaga et al., 2015). Buah terung biasa dikonsumsi sebagai sayur dan lalapan karena memiliki cita rasa yang enak serta kandungan gizi yang tinggi. Saat ini kebutuhan terung terus meningkat. Kebutuhan nasional terung pada tahun 2015 sebesar 699630 dan meningkat menjadi 740810 ton pada tahun 2016 (Badan Pusat Statistik, 2017), sehingga perlu upaya peningkatan produksi baik melalui peningkatan produktivitas maupun perluasan area tanam. Perluasan area produksi terung dapat dilakukan dengan memanfaatkan lahan-lahan sub optimal yang mengalami cekaman abiotik, seperti lahan yang bersifat salin. Masalah yang dihadapi dalam budidaya tanaman pada lahan salin adalah kadar garam yang tinggi pada tanah-tanah tersebut dapat menyebabkan pertumbuhan tanaman terhambat dan produktivitas menurun. Menurut Jouyban (2012), ada 3 metode umum yang digunakan dalam reklamasi tanah salin yaitu dengan cara pengikisan (pengorekan), pembilasan dan pencucian garam, tetapi metode ini sangat mahal dan memerlukan waktu yang lama. Alternatif lain yang dapat dilakukan adalah dengan cara penggunaan varietas yang toleran cekaman salinitas.

Penelitian mengenai pengaruh cekaman salinitas terhadap pertumbuhan tanaman budidaya terus dilakukan terutama terhadap tanaman pangan dan sayuran yang beberapa di antaranya berasal dari suku Solanaceae seperti cabe (Sharma et al., 2012), tomat (Azarmi et al., 2010), kentang (Biswas et al., 2017), dan terung (Bintoro, 1983; Santoso et al., 2012; Suliasih dan Widawati, 2016). Menurut informasi yang diperoleh dari Ghafoor et al. (2004) bahwa ambang batas salinitas tanaman terung sebesar $1.1 \mathrm{dS} \mathrm{m} \mathrm{m}^{-1}$ dengan presentase penurunan hasil sebesar $6.9 \%\left(\mathrm{dS} \mathrm{m}^{-1}\right)^{-1}$. Sejauh ini penelitian respon tanaman terung terhadap salinitas hanya terbatas pada kajian morfologi yang menunjukkan penurunan pertumbuhan dan produktivitas pada semua peubah pertumbuhan morfologi. Berdasarkan hal tersebut dinilai perlu dilakukan penelitian tentang respon fisiologi tanaman terung. Oleh karena itu, penelitian ini bertujuan untuk mempelajari respon morfologi dan fisiologi enam genotipe tanaman terung terhadap cekaman salinitas.

\section{BAHAN DAN METODE}

Penelitian ini telah dilaksanakan di Rumah Kaca Departemen Biologi dan Laboratorium Fisiologi dan Biologi Molekuler Tumbuhan, Departeman Biologi FMIPA, IPB dari bulan Juli 2014 sampai September 2015. Bahan yang digunakan ialah 6 genotipe terung (002, 032, 034, 061, 072 dan 081) koleksi Pusat Kajian Hortikultura Tropika (PKHT) IPB. Rancangan percobaan yang digunakan ialah Rancangan Acak Kelompok yang terdiri dari dua faktor yaitu faktor genotipe yang terdiri dari 6 genotipe dan faktor perlakuan salinitas $(\mathrm{NaCl})$ yang terdiri atas 4 taraf yaitu $0-1,2-4$, $5-7,8-10 \mathrm{mS} \mathrm{cm}^{-1}$. Setiap satuan percobaan diulang 5 kali sehingga diperoleh 120 unit percobaan.

\section{Penanaman dan Perlakuan Salinitas}

Enam genotipe ditanam dalam polibag $(25 \mathrm{~cm}$ x $30 \mathrm{~cm})$ di rumah kaca menggunakan media tanam pasir, sekam bakar, tanah 1:1:1 (v/v). Tanaman berumur 12 MST (Minggu Setelah Tanam) beserta media awalnya dipindahkan lagi ke polibag berukuran 35 x 40 cm dengan media tanam yang terdiri dari tanah, sekam dan kompos dengan perbandingan 1:1:3/4 (v/v). Perlakuan salinitas diberikan mulai 5 - 24 MST dan dilakukan setiap 2 hari sekali, sebanyak 300- 2000 ml larutan $\mathrm{NaCl}$.

\section{Pemeliharaan Tanaman}

Pemeliharaan tanaman meliputi penyulaman pada $3 \mathrm{MST}$, pemasangan ajir dan pengendalian hama dan penyakit. Penyemprotan pupuk cair Sampi Biogrow Complete setiap 2 hari sekali diawali pada 2 MST hingga 5 MST sebanyak $2 \mathrm{ml}$ dalam bentuk semprotan dengan konsentrasi $5 \mathrm{ml} \mathrm{L}^{-1}$. Pemberian pupuk NPK (16:16:16) diberikan dua kali yaitu ketika tanaman berumur 5 MST dalam bentuk cairan sebanyak $100 \mathrm{ml}$ dengan konsentrasi $2 \mathrm{~g} \mathrm{~L}^{-1}$ dan ketika umur $13 \mathrm{MST}$ sebanyak 2 g per pot. Pengendalian hama dan penyakit dilakukan sesuai intensitas serangan hama penyakit. 


\section{Pengamatan Peubah Morfologi dan Peubah Fisiologi}

Pengamatan tinggi tanaman dan jumlah daun dilakukan pada minggu ke 18 MST. Jumlah cabang, bobot basah tajuk dan akar diamati pada akhir percobaan (24 MST), sedangkan pengamatan bobot buah diukur setiap pemanenan buah, sedangkan pengukuran peubah fisiologi, meliputi laju fotosintesis, laju transpirasi, konduktansi stomata, dan $\mathrm{CO}_{2}$ interselular diukur menggunakan Portable Photosynthesis System tipe LI-6400 ( LI-COR Inc., USA) berumur 22 MST. Kadar air relatif (KAR) daun diukur berdasarkan metode Barr dan Weatherley (1962), sedangkan analisis kandungan prolin daun merujuk pada metode Bates et al. (1973).

\section{Analisis Data}

Data yang diperoleh dianalisis menggunakan sidik ragam $(\alpha=0.05)$ satu arah. Jika terdapat pengaruh nyata antar perlakuan pengujian dilanjutkan dengan Duncan's Multiple Range Test (DMRT). Pengolahan data menggunakan program statistik SPSS untuk windows (Versi 15). Pengelompokan genotipe terung berdasarkan kemampuan toleransinya terhadap cekaman salinitas dilakukan berdasarkan nilai Stress Susceptibility Index (SSI) (Fischer dan Maurer, 1978) dengan rumus:

$$
\mathrm{SSI}=\frac{\left(1-\frac{\mathrm{Y}}{\mathrm{Yp}}\right)}{\left(1-\frac{\mathrm{X}}{\mathrm{Xp}}\right)}
$$

Dimana $\mathrm{Y}=$ nilai pengamatan untuk satu genotipe pada kondisi tercekam salinitas, $\mathrm{Yp}=$ nilai pengamatan untuk satu genotipe pada kondisi kontrol, $\mathrm{X}=$ nilai rata-rata pengamatan untuk semua genotipe dalam kondisi cekaman salinitas, $\mathrm{Xp}=$ nilai rata-rata pengamatan untuk semua genotipe dalam kondisi kontrol. Genotipe terung dikelompokkan menjadi toleran (T) jika SSI $<0.5$, moderat (M) jika $0.5<\mathrm{SSI}<1$, dan sensitif (S) terhadap cekaman salinitas jika SSI $>1$.

\section{HASIL DAN PEMBAHASAN}

\section{Respon Morfologi Tanaman Terung terhadap Cekaman Salinitas}

Faktor genotipe dan salinitas masingmasing berpengaruh nyata terhadap semua peubah morfologi kecuali terhadap bobot basah akar yang terdapat interaksi. Pengaruh yang diberikan yaitu dapat menurunkan tinggi tanaman, jumlah daun, jumlah cabang, bobot basah tajuk dan akar serta bobot buah (Tabel 1). Semua genotipe yang diuji mengalami penurunan hasil pengukuran peubah morfologi pada perlakuan salinitas tinggi $\left(8-10 \mathrm{mS} \mathrm{cm}^{-1}\right)$. Asih et al. (2015) melaporkan bahwa perlakuan paparan garam $\mathrm{NaCl}$ dapat mempengaruhi bobot basah dan bobot kering tanaman sawi hijau. Salinitas dapat mengganggu penyerapan ion-nutrisi penting, keadaan ini diduga sebagai penyebab terganggunya sistem penyerapan air hara di dalam tanaman (Tester dan Devenport, 2003), sedangkan air merupakan bahan baku yang sangat dibutuhkan oleh tanaman untuk melakukan aktivitas metabolisme.

Tabel 1. Pengaruh genotipe dan cekaman salinitas terhadap morfologi terung

\begin{tabular}{lllllll}
\hline Perlakuan & & $\begin{array}{c}\text { Tinggi } \\
\text { Tanaman }^{1} \\
(\mathrm{~cm})\end{array}$ & $\begin{array}{c}\text { Jumlah } \\
\text { Daun }^{1} \\
(\text { helai) }\end{array}$ & $\begin{array}{c}\text { Jumlah } \\
\text { Cabang }^{2} \\
(\text { cabang) }\end{array}$ & $\begin{array}{c}\text { BB } \\
\text { Tajuk }^{2} \\
(\mathrm{~g})\end{array}$ & $\begin{array}{c}\text { Bobot }_{\text {Buah }^{2}} \\
(\mathrm{~g})\end{array}$ \\
\hline \multirow{6}{*}{ Genotipe } & 002 & $70.22 \mathrm{~b}$ & $22.35 \mathrm{c}$ & $3.60 \mathrm{~b}$ & $31.17 \mathrm{a}$ & $32.19 \mathrm{bc}$ \\
& 032 & $78.75 \mathrm{c}$ & $11.70 \mathrm{a}$ & $2.55 \mathrm{a}$ & $42.74 \mathrm{c}$ & $17.53 \mathrm{ab}$ \\
& 034 & $73.20 \mathrm{bc}$ & $17.65 \mathrm{~b}$ & $3.00 \mathrm{ab}$ & $32.52 \mathrm{ab}$ & $22.87 \mathrm{ab}$ \\
& 061 & $73.42 \mathrm{bc}$ & $16.60 \mathrm{~b}$ & $3.15 \mathrm{~b}$ & $53.04 \mathrm{~d}$ & $24.25 \mathrm{ab}$ \\
& 072 & $72.50 \mathrm{bc}$ & $15.95 \mathrm{~b}$ & $3.25 \mathrm{~b}$ & $41.23 \mathrm{bc}$ & $15.98 \mathrm{a}$ \\
& 081 & $34.76 \mathrm{a}$ & $11.10 \mathrm{a}$ & $3.25 \mathrm{~b}$ & $44.61 \mathrm{~cd}$ & $43.16 \mathrm{c}$ \\
\hline \multirow{3}{*}{$\left(\mathrm{mS} \mathrm{cm}^{-1}\right)$} & $0-1$ & $69.50 \mathrm{~b}$ & $18.43 \mathrm{c}$ & $3.70 \mathrm{~b}$ & $56.20 \mathrm{c}$ & $40.04 \mathrm{~b}$ \\
& $2-4$ & $68.63 \mathrm{~b}$ & $16.97 \mathrm{bc}$ & $3.40 \mathrm{~b}$ & $42.24 \mathrm{~b}$ & $21.86 \mathrm{a}$ \\
& $5-7$ & $68.87 \mathrm{~b}$ & $14.90 \mathrm{ab}$ & $2.86 \mathrm{a}$ & $35.75 \mathrm{ab}$ & $23.89 \mathrm{a}$ \\
\hline
\end{tabular}

Keterangan: Angka yang diikuti oleh huruf yang sama pada kolom yang sama tidak berbeda nyata berdasarkan DMRT pada $\alpha=5 \%,{ }^{1}$ : diamati pada $18 \mathrm{MST}$; ${ }^{2}$ : diamati pada $24 \mathrm{MST}$. 
Kebutuhan air yang terhambat penyerapan dan transportnya dapat menyebabkan pembelahan sel terganggu dan terhambat. Azarmi et al. (2010) melaporkan tinggi tanaman dan jumlah daun tomat menurun secara signifikan seiring meningkatnya konsentrasi salinitas. Ini salah satu bentuk adaptasi tanaman untuk mengurangi penguapan karena defisit air yang diperoleh akibat terganggunya sistem tranportasi air dan hara, sehingga tanaman menggugurkan daunnya. Media bersalinitas tinggi dapat menurunkan jumlah cabang. Hal yang sama ditegaskan oleh Wijayanti et al. (2014), bahwa cekaman salinitas dapat mempengaruhi sifat agronomi dan jumlah cabang produktif kacang tanah.

Bobot buah tanaman terung berbeda antar genotipe dan perlakuan salinitas. Pengaruh salinitas yang tinggi dapat menghasilkan buah yang berukuran kecil, berkerut bahkan terdapat buah yang memperlihatkan gejala membusuk. Selain itu, pada beberapa ulangan genotipe tidak dapat menghasilkan buah sama sekali. Suliasih dan Widawati (2016) melaporkan bahwa salinitas dapat mempengaruhi bobot basah buah terung, bahkan pada perlakuan $\mathrm{NaCl} 100 \%$ tanaman tidak dapat menghasilkan buah. Transport air yang terganggu dapat menghambat proses fotosintesis sehingga fotosintat yang dihasilkan untuk pertumbuhan dan pembentukan buah juga tidak maksimal.

Pada peubah morfologi hanya bobot basah akar yang terdapat interaksi antara perbedaan genotipe dan perlakuan salinitas (Tabel 2). Berdasakan Tabel tersebut, cekaman salinitas pada $8-10 \mathrm{mS} \mathrm{cm} \mathrm{cm}^{-1}$ menyebabkan genotipe 081 mengalami penurunan bobot basah akar paling tinggi (68.64\%), sedangkan genotipe 061 dan 072 berturut-turut hanya mengalami penurunan bobot basah akar paling rendah 15.25 dan $14.59 \%$ dari bobot basah akar pada perlakuan kontrolnya. Hal ini mengindikasikan bahwa genotipe 081 kurang mampu beradaptasi dengan cekaman salinitas. Bintoro (1983) menyatakan bahwa salinitas dapat menurunkan bobot akar kultivar terung.

\section{Respon Fisiologi Tanaman Terung terhadap Cekaman Salinitas}

Perlakuan salinitas dapat menurunkan laju fotosintesis (Gambar 1A). Nemati et al. (2011) melaporkan bahwa cekaman salinitas menyebabkan peningkatan konsentrasi ion yang bersifat racun bagi tanaman sehingga dapat menyebabkan penuaan dini dan mengurangi kemampuan fotosintesis tanaman. Mazher et al. (2007) juga menyatakan bahwa pertumbuhan tanaman dibatasi oleh penurunan laju fotosintesis secara berlebihan akibat serapan garam. Selain menurunkan laju fotosintesis, salinitas juga dapat menurunkan konduktansi stomata (Gambar 1B). Koyro (2006) menambahkan bahwa pengurangan konduktansi stomata merupakan mekanisme adaptasi untuk mengatasi garam yang berlebihan.

Salinitas juga menyebabkan penurunan laju transpirasi (Gambar 1C) akibat kurangnya pasokan air yang masuk ke dalam jaringan tanaman, sehingga tanaman melakukan penghematan air yang keluar dari jaringan tanaman melalui proses penguapan dengan cara mengurangi laju transpirasi. Ruiz-Sánchez et al. (2000) menyatakan bahwa tanaman melakukan suatu mekanisme penghindaran atau pencegahan untuk meminimalkan kehilangan air melalui transpirasi ketika stomata tertutup.

Tabel 2. Pengaruh interaksi genotipe dan cekaman salinitas terhadap bobot basah akar terung berumur 24 MST

\begin{tabular}{ccccc}
\hline \multirow{2}{*}{ Genotipe } & \multicolumn{5}{c}{ Salinitas $(\mathrm{mS} \mathrm{cm}-1)$} \\
\cline { 2 - 5 } & $0-1$ & $2-4$ & $5-7$ & $8-10$ \\
002 & 8.06 a-e & $10.02 \mathrm{e}$ & 5.84 a-e & 4.60 a-c \\
032 & 6.86 a-e & 6.00 a-e & 3.54 a & 4.52 a-c \\
034 & $9.50 \mathrm{de}$ & $4.96 \mathrm{a}-\mathrm{d}$ & 6.64 a-e & 4.50 a-c \\
061 & $9.18 \mathrm{c}-\mathrm{e}$ & $7.74 \mathrm{a}-\mathrm{e}$ & $7.66 \mathrm{a}-\mathrm{e}$ & 7.78 a-e \\
072 & $8.50 \mathrm{~b}-\mathrm{e}$ & $7.74 \mathrm{a}-\mathrm{e}$ & 6.12 a-e & 7.26 a-e \\
081 & $14.86 \mathrm{f}$ & $4.28 \mathrm{ab}$ & 5.48 a-e & 4.66 a-c \\
\hline
\end{tabular}

Keterangan: Angka yang diikuti oleh huruf yang sama dalam satu kolom dan baris yang sama tidak berbeda nyata berdasarkan DMRT pada $\alpha=5 \%$. 

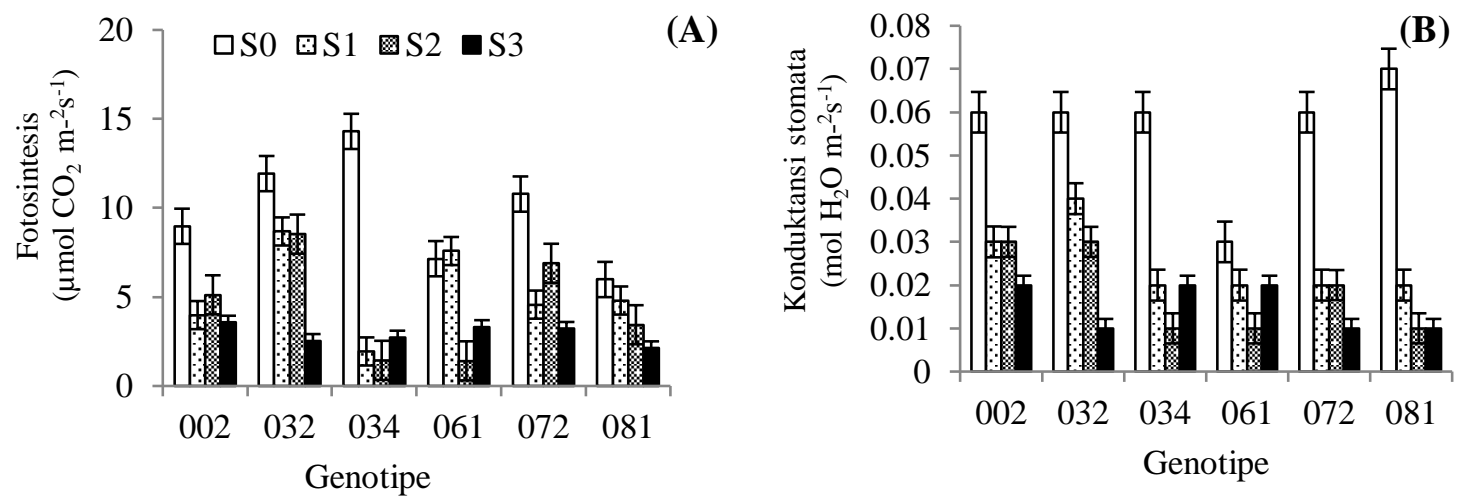

(C)
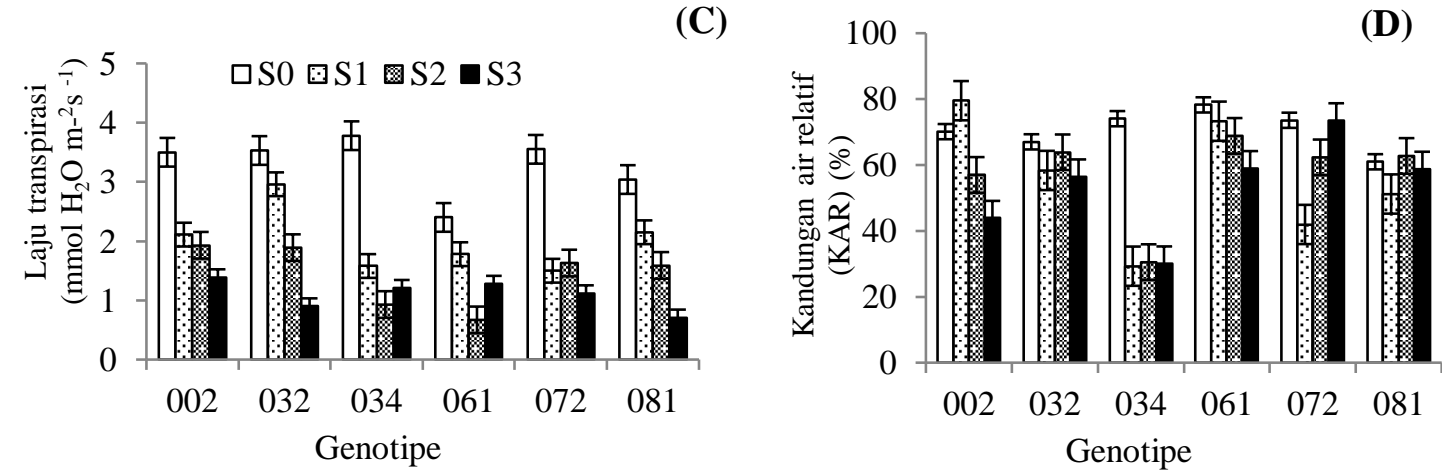

Gambar 1. Respon peubah fisiologi dari enam genotipe terung berumur 22 MST terhadap cekaman salinitas S0 (0-1 mS cm$\left.{ }^{-1}\right), \mathrm{S} 1\left(2-4 \mathrm{mS} \mathrm{cm}^{-1}\right), \mathrm{S} 2\left(5-7 \mathrm{mS} \mathrm{cm}^{-1}\right)$ dan $\mathrm{S} 3\left(8-10 \mathrm{mS} \mathrm{cm}^{-1}\right)$. (A): Laju fotosintesis, (B): Konduktansi stomata, (C): Laju transpirasi, (D): Kadar air relatif daun. Bar menunjukkan standar error.

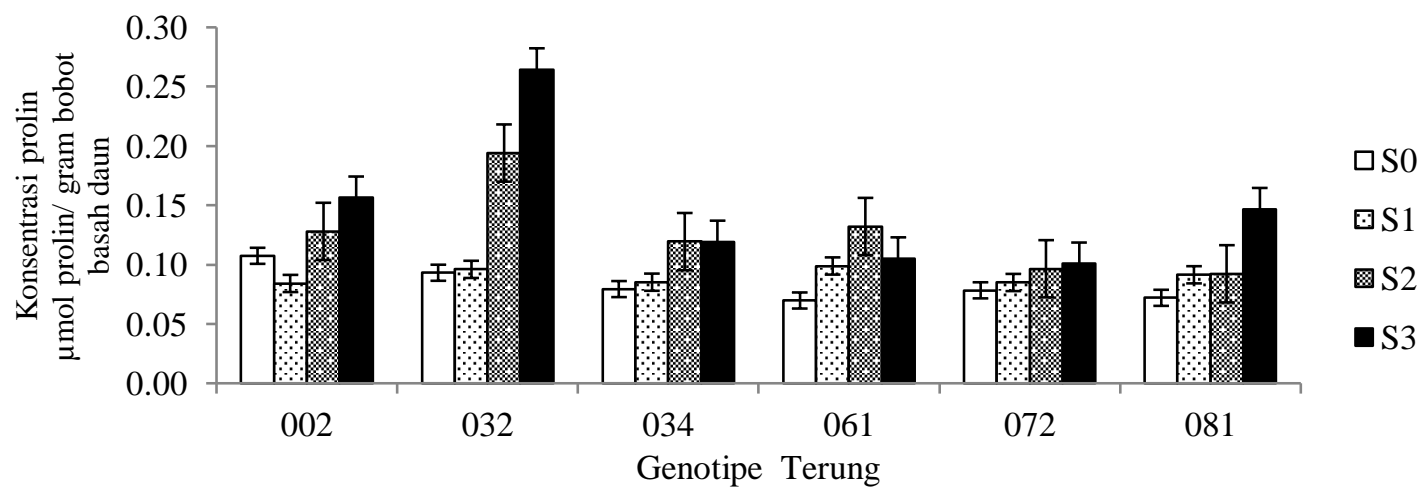

Gambar 2. Konsentrasi prolin daun enam genotipe terung berumur 24 MST pada cekaman salinitas S0 $\left(0-1 \mathrm{mS} \mathrm{cm}{ }^{-1}\right), \mathrm{S} 1\left(2-4 \mathrm{mS} \mathrm{cm} \mathrm{cm}^{-1}\right), \mathrm{S} 2\left(5-7 \mathrm{mS} \mathrm{cm}^{-1}\right)$ dan $\mathrm{S} 3\left(8-10 \mathrm{mS} \mathrm{cm} \mathrm{cm}^{-1}\right)$. Bar menunjukkan standar error.

Salinitas menurunkan kandungan air relatif (KAR) daun (Gambar 1D). Hal ini juga disebabkan karena terhambatnya penyerapan dan transport air ke dalam jaringan tanaman disebabkan oleh gangguan osmotik. Kabir et al. (2004) melaporkan bahwa cekaman salinitas mengakibatkan nilai KAR daun menurun pada tanaman tomat (Tuna, 2014).
Pada penilitian ini cekaman meningkatkan konsentrasi prolin daun (Gambar 2) pada semua genotipe. Tingkat akumulasi prolin tiap genotipe berbeda-beda. Konsentrasi prolin diketahui meningkat seiring dengan meningkatnya kadar salinitas. Genotipe peka cekaman salin menghasilkan prolin lebih banyak dibanding genotipe toleran. Ini menunjukkan bahwa genotipe beradaptasi 
dengan cara melakukan proses ormoregulasi yaitu tanaman mengeluarkan prolin yang berperan sebagai osmoregulator (Hasanah dan Trahmawati, 2014) dalam jumlah yang banyak untuk menjaga keseimbangan osmotik sel tanaman karena berhubungan dengan hilangnya turgiditas sel, selain itu fungsi prolin juga sebagai penyangga untuk menjaga $\mathrm{pH}$ redoks sitosol status sel (Verbruggen dan Hermans, 2008).

Pada peubah fisiologi, pengaruh interaksi antara faktor genotipe dan perlakuan salinitas hanya terdapat pada peubah kandungan $\mathrm{CO}_{2}$ interselular daun (Tabel 3). Pada tingkat cekaman salinitas $8-10 \mathrm{mS} \mathrm{cm}^{-2}$ genotipe 081 mengalami penurunan kandungan $\mathrm{CO}_{2}$. interselular paling tinggi yaitu sebesar $92.93 \%$ dari perlakuan kontrolnya, sedangkan genotipe 061 mengalami penuruan yang paling rendah yaitu sebesar $15.56 \%$ dari nilai kandungan $\mathrm{CO}_{2}$ interselular pada kondisi kontrol. Menurunnya konsentrasi $\mathrm{CO}_{2} \quad$ interselular yang menyebabkan enzim rubisco bekerja di bawah kapasitasnya (Ribulosa bi phosphat carboxylase/ oxidase) ke arah karboksilase, sehingga laju fotosintesis menjadi rendah. Hal ini akan berimbas terhadap pertumbuhan dan produksi tanaman.

\section{Indeks Kepekaan Salinitas}

Hasil analisis indeks kepekaan terhadap cekaman salinitas tanaman terung yang dicerminkan oleh nilai Stress Susceptibility Index (SSI). Berdasarkan rata-rata nilai SSI peubah morfologi dan fisiologi pada salinitas 57 dan 8-10 mScm mengindikasikan bahwa dari 6 genotipe yang diuji dua genotipe, yaitu 061 dan 072 dapat dikelompokkan sebagai genotipe moderat karena memiliki nilai SSI 0.71-0.73 dan genotipe 072 memiliki nilai SSI 0.66-0.91, sedangkan genotipe 002, 032, 034 dan 081 merupakan genotipe peka karena memiliki nilai SSI 0.96-1.29. (Gambar 3). Pendekatan yang sama juga digunakan Khaled et al. (2014) pada tanaman barley.

Tabel 3. Pengaruh interaksi antara genotipe dan cekaman salinitas terhadap $\mathrm{CO}_{2}$ interselular daun terung berumur $22 \mathrm{HST}$

\begin{tabular}{lrlrr}
\hline & \multicolumn{5}{c}{ Salinitas $\left(\mathrm{mS} \mathrm{cm}^{-1}\right)$} \\
\cline { 2 - 5 } \multicolumn{1}{c}{ Peubah } & $0-1$ & $2-4$ & $5-7$ & $8-10$ \\
002 & & $\left(\mu \mathrm{mol} \mathrm{CO} \mathrm{mol}^{-1}\right)$ & \\
032 & $96.83 \mathrm{a}-\mathrm{d}$ & $116.03 \mathrm{a}-\mathrm{d}$ & $81.50 \mathrm{a}-\mathrm{d}$ & $90.20 \mathrm{a}-\mathrm{d}$ \\
034 & $116.20 \mathrm{a}-\mathrm{d}$ & $109.10 \mathrm{a}-\mathrm{d}$ & $262.00 \mathrm{~b}-\mathrm{d}$ & $171.10 \mathrm{a}-\mathrm{d}$ \\
061 & $46.90 \mathrm{a}-\mathrm{c}$ & $207.30 \mathrm{a}-\mathrm{d}$ & $162.68 \mathrm{a}-\mathrm{d}$ & $120.00 \mathrm{a}-\mathrm{d}$ \\
072 & $90.63 \mathrm{a}-\mathrm{d}$ & $194.83 \mathrm{a}-\mathrm{d}$ & $96.20 \mathrm{a}-\mathrm{d}$ & $76.53 \mathrm{a}-\mathrm{d}$ \\
081 & $32.19 \mathrm{a}$ & $273.00 \mathrm{~cd}$ & $113.61 \mathrm{a}-\mathrm{d}$ & $73.86 \mathrm{a}-\mathrm{d}$ \\
\hline
\end{tabular}

Keterangan: Angka yang diikuti oleh huruf yang sama dalam satu kolom dan baris yang sama tidak berbeda nyata berdasarkan DMRT pada $\alpha=5 \%$.

口SSI pada cekaman salinitas $5-7 \mathrm{mS} / \mathrm{cm} \square$ SSI pada cekaman salinitas $8-10 \mathrm{mS} / \mathrm{cm}$

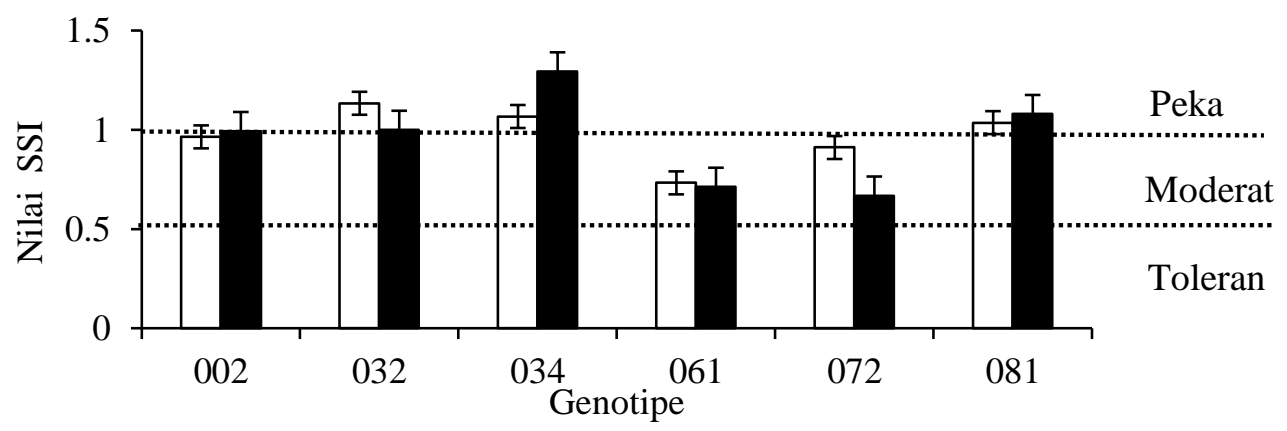

Gambar 3. Indeks kepekaan terhadap cekaman salinitas (SSI) yang dihitung berdasarkan peubah morfologi dan fisiologi 6 genotipe terung terhadap cekaman salinitas. Pengelompokkan toleransi ke dalam toleran $(\mathrm{T})$ jika $\mathrm{SSI}<0.5$, moderat $(\mathrm{M})$ jika $0.5 \leq \mathrm{SSI} \leq 1$, dan peka $(\mathrm{P})$ terhadap cekaman salinitas jika SSI $>1$. 


\section{KESIMPULAN}

Cekaman salinitas sampai $8-10 \mathrm{mS} \mathrm{cm}^{-1}$ terhadap 6 genotipe terung telah terbukti menyebabkan penurunan terhadap keragaman morfologi meliputi tinggi tanaman, jumlah daun, jumlah cabang, bobot basah tajuk, bobot basah akar dan bobot buah dan menekan beberapa proses fisiologi tanaman meliputi laju fotosintesis, laju transpirasi, konduktansi stomata, $\mathrm{CO}_{2}$ interselular, kandungan air relatif dan meningkatkan akumulasi prolin di jaringan daun. Berdasarkan nilai SSI, genotipe 061 dengan nilai SSI 0.71-0.73 dan 072 dengan nilai SSI 0.66-0.91 dapat dikelompokkan sebagai genotipe moderat terhadap salinitas, sedangkan genotipe 002, 032, 034 dan 081 merupakan genotipe moderat ke peka karena memiliki nilai SSI 0.96-1.29.

\section{UCAPAN TERIMA KASIH}

Terimakasih disampaikan kepada Kemristek DIKTI atas beasiswa BPPDN 2013 dan kepada Pusat Kajian Hortikultura Tropika (PKHT) melalui Bapak Prof. Dr. Ir. Sobir, M.Si. atas dana penelitian yang diberikan.

\section{DAFTAR PUSTAKA}

Asih, E.D., Mukarlina, I. Lovadi. 2015. Toleransi tanaman sawi hijau (Brassica juncea L.) terhadap cekaman salinitas garam NaCl. Protobiont. 4: 203-208.

Azarmi, R., R.D. Taleshmikail, A. Gikloo. 2010. Effects of salinity on morphological and physiological changes and yield of tomato in hydroponic system. J. Food. Agric. Environ. 8: 573-576.

[BPS] Badan Pusat Statistik. 2017. Konsumsi buah dan sayur susenas maret 2016. http://gizi.depkes.go.id/wp-content/uploads/ 2017/01/Paparan-BPS-Konsumsi-BuahDan-Sayur.pdf. [22 Mei 2017].

Barr, H.D., P.E. Weatherley. 1962. A reexamination of the relative turgidity technique for estimating water deficit in leaves. Aust. J. Biol. Sci. 15: 413428.

Bates, L.S., R.P. Waldren, I.D. Teare. 1973. Rapid determination of free proline for water stress studies. Plant and Soil. 39: 205-207.

Bintoro, M.H. 1983. Pengaruh $\mathrm{NaCl}$ terhadap pertumbuhan tanaman terung $\mathrm{cv}$. Senryo dan cv. Akanasu. Bul. Agron. 14: 32-49.

Biswas, M.S., M.R. Islam, M. Zakaria. 2017. Evaluation of indigenous potato challisha (Solanum tuberosum L. Cv. Challisha) somaclonals tolerance to salinity in vitro. Journal of Tropical Life Science. 7: 77-82.

Fischer, R.A., R. Maurer. 1978. Drought resistance in spring wheat cultivars. Aust. J. Agric. 29: 897-912.

Ghafoor, A., M. Qadir, G. Murtaza. 2004. SaltAffected Soils: Principles of Management. Allied Book Centre, Urdu Bazar, Lahore. (ISBN 969-547). 304 p.

Hasanah, Y., N. Rahmawati. 2014. Produksi dan fisiologi kedelai pada kondisi cekaman kekeringan dengan aplikasi Bradyrhizobium japonicum yang diberi penginduksi genistein. J. Agron. Indonesia. 42:110-117.

Jouyban, Z. 2012. The effect of salt stress on plant growth. Technical Journal Engineering Applied Sciences. 2:7-10.

Kabir, S.M.L., M.M. Rahman, M.B. Rahman, M.M. Rahman, S.U. Ahmed, 2004. The dynamics of probiotics on growth performance and immune response in broilers. Int. J. Poult. Sci. 3: 361-364.

Khaled, A.B., H. Taoufik, M. Elhem, F. Ali. 2014. Assessment of salt tolerance of some Tunisian Barley accessions using gas exchange atributes and $\mathrm{Na}^{+}$content. Int. J. Curr. Microbiol. App. Sci. 3: 647661. 
Koyro, H.W. 2006. Effect of salinity on growth, photosynthesis, water relations and solute composition of the potential cash crop halophyte Plantago coronopus L. Environmental and Experimental Botany. 56: $136-146$.

Mazher, A.A., E.F. El-Quesni, M.M. Farahat. 2007. Responses of ornamental and woody trees to salinity. World J. Agric. Sci. 3: 386-395.

Nemati, I., F. Moradi, S. Gholizadeh, M.A. Esmaeili, M.R. Bihamta. 2011. The effect of salinity stress on ions and soluble sugars distribution in leaves, leaf sheaths and roots of rice (Oryza sativa L.) seedlings. Plant Soil Environ. 57: 2633.

Ruiz-Sánchez, M.C., R. Domingo, A. Torrecillas, A. Pérez-Pastor. 2000. Water stress preconditioning to improve drought resistance in young apricot plants. Plant Sci. 156: 245-251.

Santoso, A.M., L. Riska, M. Rizal. 2012. Pengaruh cekaman salinitas terhadap morfologi akar terung kopek lokal. Hal. 569-573. Dalam Santoso A.M., editor. Prosiding Seminar Nasional Biologi, Sains, Lingkungan, dan Pembelajaran dalam Upaya Peningkatan Daya Saing Bangsa. Kediri 11 Agustus 2012.

Sharma, C., N. Singh, K. Pal. 2012. The effect of salt stress on biochemicals of chili at seedling level. International Journal of Pharma Professional Research 3: 572577.

Sinaga, E., M. S. Rahayu, A. Maharijaya. 2015. Seleksi toleransi kekeringan in vitro terhadap enam belas aksesi tanaman terung (Solanum melongena L.) dengan polietilena glikol (PEG). J. Hort. Indonesia. 6(1): 20-28.

Suliasih, Widawati. 2016. Pengaruh salinitas dan inokulan bakteri terhadap pertumbuhan tanaman terung (Solanum melongena L.). Ber. Biol. 15:17-25.

Tester, M., R. Davenport. 2003. $\mathrm{Na}^{+}$tolerant and $\mathrm{Na}^{+}$transport in higher plants. Annals Bot. 91:503-527.

Tuna, A.L. 2014. Influence of foliarly applied different triazole compounds on growth, nutrition, and antioxidant enzyme activities in tomato (Solanum lycopersicum L.) under salt stress. Aust. J. Crop. Sci. 8: 71-79.

Verbruggen, N., C. Hermans. 2008. Proline accumulation in plants. Amino Acids. 35: 753-759.

Wijayanti, W., Taryono, Toekidjo. 2014. Keragaan 29 galur kacang tanah (Arachis hypogaea L.) pada kondisi salin. Vegetalika. 3: 40-51. 